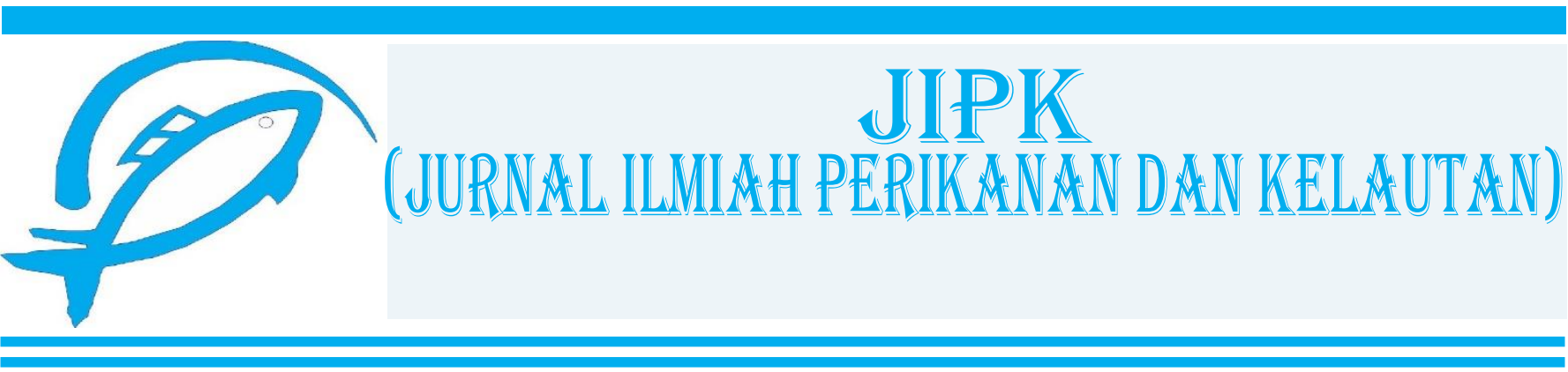

Short Communication

\title{
Application of Liquid Smoke from Coconut Shell in Tandipang (Dussumeiria acutta) Smoked Fish to Extend Shelf Life
}

\author{
Dyah Ayu Rakhmayeni' ${ }^{1}$ TattyYuniarti²*iD, Sukarno $^{3}$ \\ ${ }^{1}$ Program Study of Fisheries Resource Management, Fisheries Product Processing Industry, Jakarta Technical University of \\ Fisheries. Indonesia \\ ${ }^{2}$ Department of Fisheries Extension, Jakarta Technical University of Fisheries, Cikaret St No. 1, Bogor. Indonesia \\ ${ }^{3}$ Department of Food Science and Technology. Fateta, IPB University, Dramaga IPB Campus, Bogor. Indonesia
}

\section{OPEN

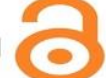 \\ ACCESS}

\section{ARTICLE INFO}

Received: July 16, 2020

Accepted: September 26, 2020

Published: September 27, 2020

*) Corresponding author:

E-mail:tatty.yuni@gmail.com

Keywords:

ASLT

Liquid Smoke

Shelf Life

Tandipang Fish

This is an open access article under the CC BY-NC-ND license (http://creativecommons.org/licenses/by-nc-nd/4.0/)

\section{Abstract}

Fumigation using liquid smoke produces smoked fish products with a smoky flavor character and can increase shelf life. The research objective was to determine the shelf life of the tandipang fish which was processed using liquid smoking. The test was carried out by storing smoked fish in an incubator at different temperatures $30{ }^{\circ} \mathrm{C}, 40^{\circ} \mathrm{C}$, and $50^{\circ} \mathrm{C}$ with three replications for 5 weeks (35 days). The samples prepared at each temperature were kept in an incubator for five weeks. The parameters tested for estimating shelf life are using the test data aw (activity water), peroxide number, and TPC (total plate count). The three parameters are selected by one parameter to calculate the shelf life of liquid smoked tandipang fish which is considered to greatly affect the quality degradation during storage. The aw parameter is used to determine the shelf life because it has a high $\mathrm{R}^{2}$ value with an activation energy of $86972.75 \mathrm{~J} /$ mol.K. Estimation of shelf life of liquid cured fish at room temperature using aw parameter is 23.2 weeks or 5.8 months.

Cite this as: Rakhmayeni, D. A., Yuniarti, T., \& Sukarno. (2020). Application of Liquid Smoke from Coconut Shell in Tandipang (Dussumeiria acutta) Smoked Fish to Extend Shelf Life. Jurnal Ilmiah Perikanan dan Kelautan, 12(2):315-323. http://doi.org/10.20473/jipk.v12i2. 20790 


\section{Introduction}

Fumigation is a method of preservation with added salt that has been applied to daily needs. Smoked fish is one of the most popular fish products by the public (Belichovska et al., 2019). Smoking is generally combined with a drying technique. Drying aims to reduce water content to the limit of the development of the development of organisms and enzyme activities that cause decay so that the dried product has a longer shelf life (Agustina et al., 2013). Traditional smoking uses high temperatures on direct heating and the fish come into contact with smoke from incomplete wood burning (pyrolysis). This smoking process can cause fish to contain harmfull compounds, likes polycyclic aromatic hydrocarbons (PAH4). Benzo( a )pyrene $(\mathrm{BaP})$ is one type of PAH4 (Hokkanen et al., 2018). Traditional processed smoked fish (tilapia, nile, milkfish, little tuna, marine catfish, mackerel, canine catfish and stingray) showed a higher BaP (0.03 to $4.58 \mathrm{ppb})$ (Swastawati et al. 2015). Fumigation using liquid smoke is currently being widely used in various types of fish, namely skipjack tuna, tuna, catfish, snakehead fish, eels, catfish (Utomo et al., 2012). The advantages of liquid smoking are shorter smoking time, controllable temperature, longer product durability, the appearance of smoked fish is more uniform and environmentally friendly (Lokollo et al., 2012).

Tandipang fish (Dussumieria acuta) are small pelagic fish that live in pelagic areas near the coast, in groups, and likes calm, scattered waters wide in the Indo Pacific region. This fish is a member of the Clupeidae family caught in the waters of Kendari Bay (Asriyana et al., 2010). Japuh fish is a tandipang fish that is processed by smoking and drying traditionally (Karapang et al., 2013). No one has yet conducted research on tandipang fish treated with liquid smoking. The different methods of smoking process can result in a different shelf life of the product. Different smoking methods such as traditional hot smoking and fumigation using liquid smoke result in different shelf life (Bhuyan et al., 2018). Coconut shell liquid smoke which is traded consists of three grades. All of these grades contain the compound janis acetic acid, aldehyde, and ketones. The higher the grade (grade 1), the less the number of PAHs (Mulyawanti et al., 2019). However grade 3 has high antimicrobial properties. This antimicrobial ability is closely related to phenol compounds (Kailaku et al., 2017). Fumigation using liquid smoke produces smoked fish products with a smoky flavor character and can increase shelf life (Alcicek, 2014).
Liquid smoke is the result of direct or indirect combustion vapor condensation of materials containing a lot of carbon, likes organic acid and phenols and other compounds (Lombok et al., 2014). Pyrolysis of wood produces phenol, carbonyl, and organic acids which affect the taste, color, and anti-microbial properties of liquid smoke (Lingbeck et al., 2014). The shelf life of a food product must be stated on the packaging label according to PP RI Number 69 of 1999. Wiguna (2011) states that the purpose of including expiration time is to provide information to consumers about the time limit for food consumption, so that the seller can regulate the food stock to be sold and help manufacturers in control of product quality. The method of estimating shelf life can be done using the Extended Storage Study (ESS) and ASLT (Accelerated Shelf Life Testing) methods (Harris and Fadli, 2014). Herawati (2008) stated that the ASLT method was chosen because the time needed for testing was shorter with a good level of accuracy.

The ASLT (Accelerated Shelf Life Testing) method is a method that is widely used in determining shelf life. The Arrhenius Model ASLT method uses an acceleration temperature which can cause accelerated product deterioration (Hasany et al., 2017). Haryati et al., (2014) state that the Arrhenius model describes the relationship between temperature and the rate of deterioration. Several parameters that can be used to determine product deterioration are TBA, TPC, organoleptic, aw, and peroxide number. During the storage period there will be chemical reactions such as fat oxidation which can cause decreased product resistance. Microbial growth during storage can reduce the sensory value of product acceptance (Putri et al., 2018). Physical changes that occur during storage include hard or soft texture, rancidity, and discoloration (Abraha et al., 2018). This study aims to determine the shelf life of tandipang fish processed using liquid smoking.

\section{Material and Method}

\subsection{Material}

The materials used in this study were tandipang fish with 3\% immersion for 45 minutes, nylon LDPE plastic, liquid smoke. The tandipang fish (japuh) used comes from the Karangantu fishing port, Serang Regency. Liquid smoke obtained from CV. Wulung Prima. The chemicals used $\mathrm{NaCl}, \mathrm{CH}_{3} \mathrm{COOH}$, chloroform. potasium iododa (KI), starch indicator and sodium thiosulphate $\left(\mathrm{Na}_{2} \mathrm{~S}_{2} \mathrm{O}_{3}\right)$ (Merck). The equipmments of this reseach used oven incubator (Memmert), drying machine, allumunium parapara and equipments for chemical analysis used UV-Vis spectrophotometer (Shimadzu) and glassware (Duran). 


\subsection{Method}

The test was carried out by storing smoked fish in an incubator at different temperatures, namely $30{ }^{\circ} \mathrm{C}$, $40{ }^{\circ} \mathrm{C}$, and $50{ }^{\circ} \mathrm{C}$ with three replications for 5 weeks (35 days). Observations were made every $0,1,2,3,4$ and 5 weeks for each storage temperature. At each temperature, 15 samples were prepared and kept in an incubator for five weeks. The parameters tested for estimating shelf life are using the test data $\mathrm{a}_{\mathrm{w}}$ (activity water), peroxide number, and TPC (total plate count). Aw analyses according to Belit (2009). Peroxide values were analyzed by method AOCS Cd-8b-90 (AOCS, 1998). TPC testing uses work procedures acoording to SNI 2725: 2013. Analysis of determining the shelf life can be seen as follows (Phimolsiripol et al., 2011).

$$
\begin{aligned}
& \text { Order } 0 \\
& t=\frac{\left(Q_{0}-Q\right)}{k}
\end{aligned}
$$

$$
\begin{aligned}
& \text { Order } 1 \\
& t=\frac{\ln Q_{t}-\ln Q_{0}}{k}
\end{aligned}
$$

The $\mathrm{k}$ value that has been obtained is then linked to temperature using the Arrhenius equation (3),

$$
k=k_{g} e^{-(E a / R T)}
$$

The above equation can be an equation

$$
\ln =\ln k_{0}-\frac{E a}{R} \frac{1}{T}
$$

Thus, plotting the curve between In $\mathrm{k}$ and 1 / $\mathrm{T}$ produces a straight line that can extrapolate the shelf life of the product at other temperature levels and the energy activity of the slope multiplied by the gas constant $(1.986 \mathrm{cal} / \mathrm{mol}$ $\mathrm{K}$ or $8.314 \mathrm{~J} / \mathrm{mol} . \mathrm{K}$ )

Information :

$\mathrm{Q}_{0}=$ day 0 start score

$\mathrm{Q}=$ critical score

$\mathrm{K}=$ reaction speed constant

$\mathrm{t}$ = storage time

$\mathrm{Ea}=$ activation energy

$\mathrm{T}$ = absolute temperature

\section{Results and Discussions}

\subsection{Determination of chemical parameter}

Basic observations were carried out descriptively about the physical changes in the liquid smoke tandipang fish during storage. The first week of smoked fish samples at each temperature treatment had not experienced any physical changes.
The second week sample at $50^{\circ} \mathrm{C}$ showed a change in the smell of liquid smoke which was very pungent, while the samples at 30 and $40{ }^{\circ} \mathrm{C}$ had not shown any changes. The third week of the sample at $30{ }^{\circ} \mathrm{C}$ showed a change in texture, namely being slightly wet, the sample at $40{ }^{\circ} \mathrm{C}$ had not shown any changes, and the sample at $50{ }^{\circ} \mathrm{C}$ the aroma was more pungent. The fourth week sample at $30^{\circ} \mathrm{C}$ shows a soft texture and a pungent odor, the sample at $40{ }^{\circ} \mathrm{C}$ shows a dense texture, the fish smell is strong, dry, and golden brown, and the $50{ }^{\circ} \mathrm{C}$ sample shows a more pungent aroma of liquid smoke. and the fish is getting dry. The fifth week of storing samples at $30{ }^{\circ} \mathrm{C}$ shows a soft texture and pungent fish aroma, samples at $40{ }^{\circ} \mathrm{C}$ show strong fish scent, dense texture, and dry, and samples at $50{ }^{\circ} \mathrm{C}$ show a dense, dry texture and smoky aroma. liquid is very stinging.

The decline in the quality of food products can be seen from changes in quality attributes, so it is necessary to measure the shelf life (Putri et al., 2018). The research on estimating the shelf life of liquid smoked tandipang fish used three test parameters, namely $\mathrm{a}_{\mathrm{w}}$ (activity water), peroxide number, and Total Plate Count (TPC). The changes were observed for each parameter once a week for five weeks. The value of $a_{w}$ (activity water) is the amount of free water in food needed for microbial growth (Danarsi and Noer, 2016). Therefore, $a_{w}$ is one of the factors that affect the damage to food products (Nanlohy, 2014). The number of microbes in food is determined by the value $a_{w}$. The lower the $a_{w}$ value, the longer the product has a shelf life. The analysis results showed an increase in activity water during storage at $30^{\circ} \mathrm{C}$. The test results at week five showed that the $\mathrm{a}_{\mathrm{w}}$ value at $30{ }^{\circ} \mathrm{C}$ was 0.737 . The results showed that the $\mathrm{a}_{\mathrm{w}}$ values were in the range of 0.317 to 0.737 (Table. 1 ). The $a_{w}$ value is still below the requirements for microbial growth. The $\mathrm{a}_{\mathrm{w}}$ value level of bacteria cannot grow in smoked tandipang fish products. The requirements for viable microbes are 0.9 (Winarno, 2007). Although at low $\mathrm{a}_{\mathrm{w}}$ it still allows bacteria to exist, like $B$. cereus, being a spore-forming bacterium. It can be osmotolerant at both reduced and elevated temperatures (Ijabadeniyi and Pillay, 2017). Najih et al. (2014) stated that the chemical composition of liquid smoke absorbed by fish meat is influenced by the length of the smoking process. The more liquid smoke composition is absorbed, the less water content in the fish meat will cause the unavailability of free water needed for the reproduction of microorganisms.

Table 1. $\mathrm{a}_{\mathrm{W}}$ value changes during storage at different temperatures

\begin{tabular}{cccc}
\hline Week & \multicolumn{3}{c}{ Temperatures } \\
\cline { 2 - 4 } & $\mathbf{3 0}$ & $\mathbf{4 0}$ & $\mathbf{5 0}$ \\
\hline $\mathbf{0}$ & $0.667 \pm 0.02$ & $0.667 \pm 0.02$ & $0.667 \pm 0.02$ \\
$\mathbf{1}$ & $0.663 \pm 0.01$ & $0.657 \pm 0.01$ & $0.607 \pm 0.06$ \\
$\mathbf{2}$ & $0.664 \pm 0.03$ & $0.649 \pm 0.03$ & $0.472 \pm 0.07$ \\
$\mathbf{3}$ & $0.691 \pm 0.04$ & $0.627 \pm 0.02$ & $0.382 \pm 0.05$ \\
$\mathbf{4}$ & $0.687 \pm 0.07$ & $0.622 \pm 0.02$ & $0.351 \pm 0.03$ \\
$\mathbf{5}$ & $0.737 \pm 0.03$ & $0.587 \pm 0.04$ & $0.317 \pm 0.01$ \\
\hline
\end{tabular}


Peroxides are an indicator of rancidity, which is a common quality problem in food products. The peroxide number test is usually carried out in conjunction with other tests to determine the degree of degradation of food over the shelf life (Schlossman et al., 2015). Peroxides are formed due to the heating process, causing damage to the grease or oil. Ketaren (2012) states that foodstuffs will be rejected by consumers if they have a peroxide value of 10-20 meq / Kg. The peroxide value of smoked tandipang fish during storage was still below this threshold, namely 2.27-7.13 (Table 2). The high peroxide number is indicated by the appearance of a rancid odor in the food. The formation of a rancid odor is due to the presence of aldehyde and ketone fatty acids not by peroxides, so an increase in the peroxide number is an indicator that the fat in food will smell rancid (Sanger, 2010). Fatty food products are prone to rancidity during the storage process (Maharani et al., 2012).

Table 2. Change in the value of the peroxide value (meq/Kg) during storage at different temperatures

\begin{tabular}{cccc}
\hline Week & \multicolumn{3}{c}{ Temperatures } \\
\cline { 2 - 4 } & $\mathbf{3 0}$ & $\mathbf{4 0}$ & $\mathbf{5 0}$ \\
\hline $\mathbf{0}$ & $7.13 \pm 0$ & $7.13 \pm 0$ & $7.13 \pm 0$ \\
$\mathbf{1}$ & $6.31 \pm 1.36$ & $5.20 \pm 1.34$ & $3.62 \pm 0.72$ \\
$\mathbf{2}$ & $5.72 \pm 2.36$ & $4.97 \pm 0.68$ & $6.09 \pm 1.57$ \\
$\mathbf{3}$ & $5.18 \pm 0.23$ & $5.38 \pm 0.25$ & $4.79 \pm 1.25$ \\
$\mathbf{4}$ & $4.38 \pm 0.91$ & $2.27 \pm 0.78$ & $4.45 \pm 0.35$ \\
$\mathbf{5}$ & $5.49 \pm 0.67$ & $5.34 \pm 1.82$ & $5.02 \pm 0.94$ \\
\hline
\end{tabular}

Microbes are one of the causes of damage to food products which are very dangerous for consumers. Bacteria are a type of microbe that contaminate fishery products. The TPC test results for smoked tandipang fish have met the quality standards based on SNI 2725: 2013 (Table 3). The standard for TPC is $\leq 5.0 \times 104$ colonies / gram. The number of bacteria at storage temperature of $30{ }^{\circ} \mathrm{C}$ tends to be higher than at $40{ }^{\circ} \mathrm{C}$ and $50{ }^{\circ} \mathrm{C}$. This is because bacteria can grow well at temperatures of 30-37 ${ }^{\circ}$ C (Hadinoto et al, 2016). Several microbials that can grow on smoked fish include Enterobacteriaceae, Escherichia coli, Bacillus cereus, Clostridium perfringens, yeasts, and molds. Salmonella spp., Listeria monocytogenes, and Staphylococcus aureus were not found in smoked fish (Anihouvi et al, 2019).
Liquid smoke from coconut shell contains components such as phenol, carbonyl, organic acids, low degree $\mathrm{pH} 2$, which has antioxidant and anti-microbial properties (Salokoa et al, 2014). However, the number of bacteria in the tandipang fish is still within safe limits. The number of bacteria during storage does not exceed the limit due to the use of liquid smoke. The bioactive compounds in liquid smoke can suppress microbial growth.

\subsection{Estimated Shelf Life}

The shelf life of a food can be defined as the time period within which the food is safe to consume or has an acceptable quality to consumers (Bin et al., 2013). Estimating shelf life can be done using the Extended Storage Study (ESS) and ASLT (Accelerated Shelf Life Testing) methods. The ESS used to used to estimate the shelf life of products stored at room temperature. Sutanaya et al., (2018) uses ESS to determine the shelf life of fish fillets soaked in $6 \%$ liquid smoke for 30 minutes and then drained 15 minutes without heating, resulting in a shelf life of tuna fish fillets for 54 hours. Hasany et al., (2017) stated that the estimation of shelf life of the Arrhenius model ASLT method uses acceleration temperatures in order to accelerate reactions that cause product damage. Phimolsiripol and Suppakul (2016) stated the Arrhenius model is a classical model that relates the rate of a chemical reaction to the changes in temperature. The storage of food products with the Arrhenius model is carried out at a minimum of three extreme storage temperatures. Reactions that affect the reduction of product shelf life based on a typical physicochemical, chemical or microbial index include: zero order (quality of frozen food, Maillard browning) and first order (loss of vitamins, loss of oxidative color, microbial growth) (Phimolsiripol and Suppakul, 2016).

The results of observations on each parameter of the rate of temperature reduction were calculated using the Arrhenius plot with the $\mathrm{ln} \mathrm{k}$ relationship graph as the $\mathrm{y}$ axis and temperature as the $\mathrm{x}$-axis (Putri et al, 2018). Determination of the shelf life of liquid smoked tandipang fish was carried out by storage at three different temperatures, namely $30{ }^{\circ} \mathrm{C}, 40^{\circ} \mathrm{C}$, and $50{ }^{\circ} \mathrm{C}$. To determine the final quality of liquid smoked tandipang fish, storage is carried out for 5 weeks and observation once a week.

Table. 3 Changes in TPC value (colony / g) during storage at different

\begin{tabular}{cccc}
\hline Wekk & \multicolumn{3}{c}{ Temperatures } \\
\cline { 2 - 4 } & $\mathbf{3 0}$ & $\mathbf{4 0}$ & $\mathbf{5 0}$ \\
\hline $\mathbf{0}$ & $6.4 \times 10^{3} \pm 0$ & $6.4 \times 10^{3} \pm 0$ & $6.4 \times 10^{3} \pm 0$ \\
$\mathbf{1}$ & $4.46 \times 10^{3} \pm 1.15 \times 10^{3}$ & $4.86 \times 10^{3} \pm 2.7 \times 10^{3}$ & $3.36 \times 10^{3} \pm 6.5 \times 10^{2}$ \\
$\mathbf{2}$ & $2.93 \times 10^{3} \pm 1.1 \times 10^{3}$ & $1.83 \times 10^{3} \pm 6.65 \times 10^{2}$ & $2.23 \times 10^{3} \pm 1.85 \times 10^{3}$ \\
$\mathbf{3}$ & $3.46 \times 10^{3} \pm 1.93 \times 10^{3}$ & $3.16 \times 10^{3} \pm 3.49 \times 10^{3}$ & $1.63 \times 10^{3} \pm 1.01 \times 10^{3}$ \\
$\mathbf{4}$ & $5.36 \times 10^{3} \pm 2.7 \times 10^{3}$ & $3.18 \times 10^{3} \pm 1.97 \times 10^{3}$ & $1.88 \times 10^{3} \pm 1.07 \times 10^{3}$ \\
$\mathbf{5}$ & $3.63 \times 10^{3} \pm 1.4 \times 10^{3}$ & $2.32 \times 10^{3} \pm 2.54 \times 10^{3}$ & $4.1 \times 10^{3} \pm 1.01 \times 10^{3}$ \\
\hline
\end{tabular}


Rakhmayeni et al./ JIPK, 12 (2):315-323

Table. 4 Equation of Linear Regression for Each Quality Parameter

\begin{tabular}{llccc}
\hline Quality Parameters & \multicolumn{1}{c}{$\begin{array}{c}\text { Ordo } 0 \\
\text { Linier equation }\end{array}$} & $\mathrm{R}^{2}$ & Linier equation & $\mathrm{R}^{2}$ \\
\hline $\mathrm{aw}$ & $\mathrm{Y}=8531.2 \mathrm{x}+23.559$ & 0.8032 & $\mathrm{Y}=10461 \mathrm{x}+30.256$ & 0.8253 \\
TPC & $\mathrm{Y}=0.0001+0.004$ & 0.3095 & $\mathrm{Y}=3519.3 \mathrm{x}+9.016$ & 0.482 \\
Peroxide value & $\mathrm{Y}=2109.9 \mathrm{x}-7.7124$ & 0.4612 & $\mathrm{Y}=280.1 \mathrm{x}-11.806$ & 0.3167 \\
\hline
\end{tabular}
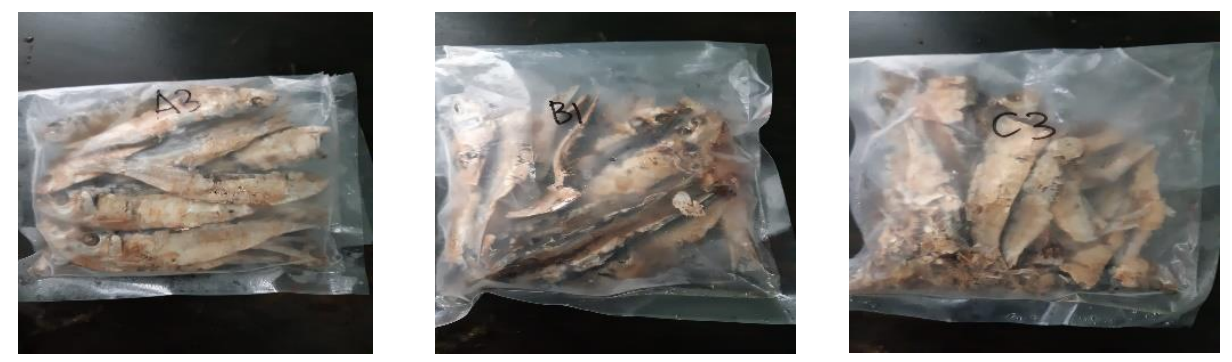

Figure. 1 Tandipang Fish Smoke

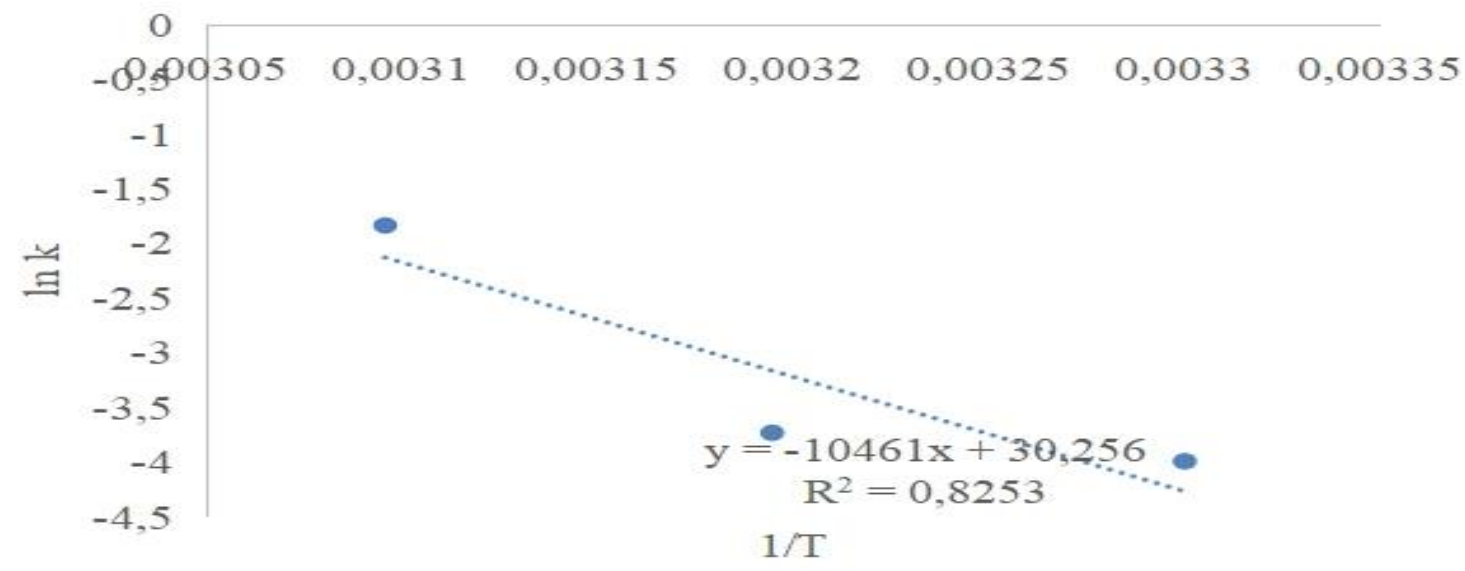

Figure. 2 Kinetics equation of the order reaction of 1 aw

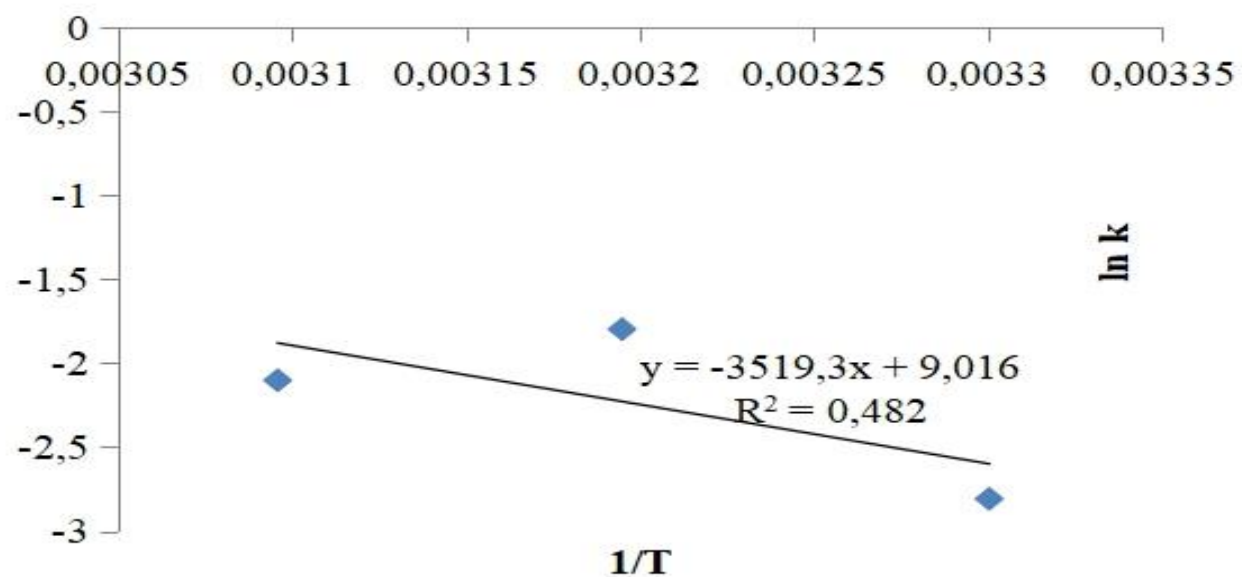

Figure. 3 Kinetics equation of the order reaction of 1 TPC 


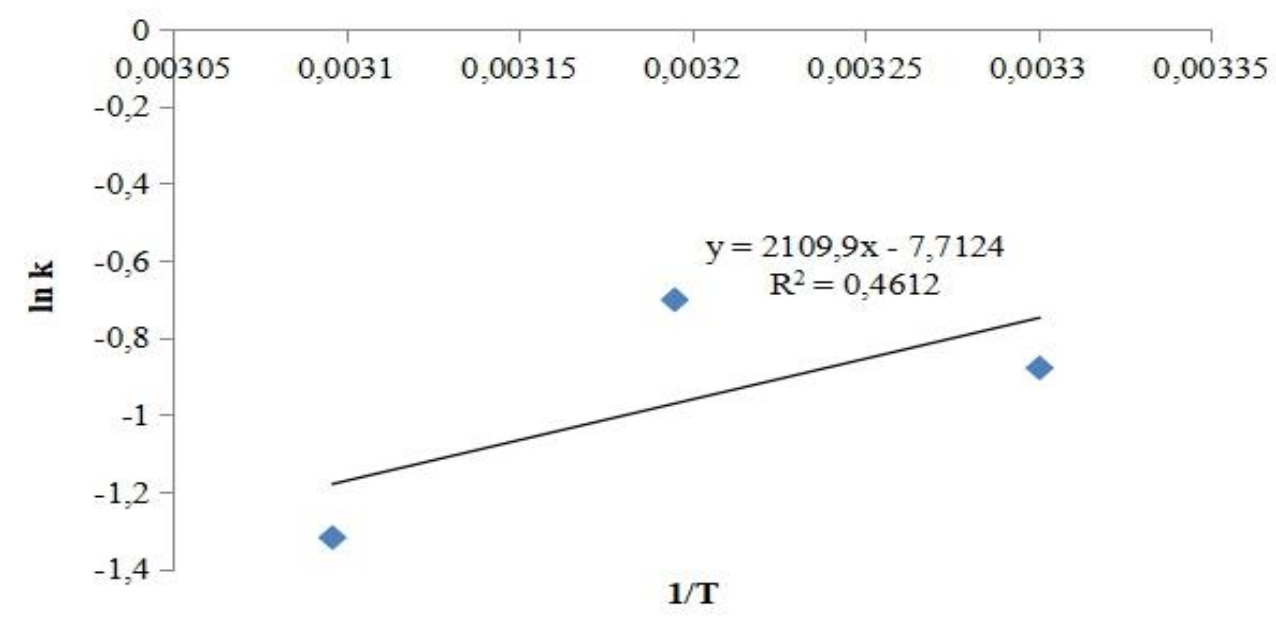

Figure. 4 Kinetics equation of the order reaction of 0 peroxyde value

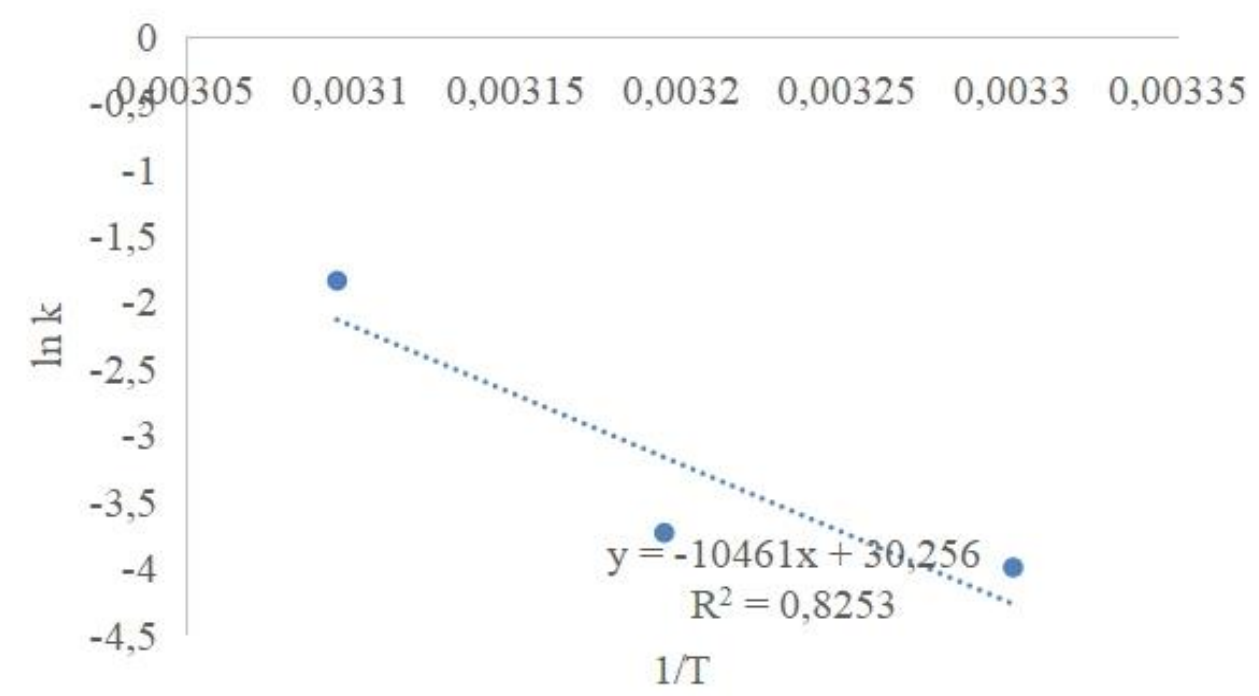

Figure. 5 The relationship between $\ln \mathrm{k}$ and storage temperature (1 / T)

Estimation of shelf life is calculated using a linear regression equation of three parameters, namely $\mathrm{a}_{\mathrm{w}}$, peroxide number, and TPC. The determination of the order for each parameter is that if the first order correlation coefficient ( $\mathrm{R}^{2}$ order one) is greater than the zero order coefficient ( $\mathrm{R}^{2}$ order zero) then the rate of decline follows the order one reaction and vice versa (Swadana et al, 2014). The linear regression equations for order 0 and order 1 for each quality parameter are presented in Table 4. The correlation coefficient used on parameter $\mathrm{a}_{\mathrm{w}}$ is order 1 (Figure. 2). The correlation coefficient used on parameter TPC is order 1 (Figure. 3). The correlation coefficient used on parameter peroxyde value is order 0 (Figure. 4).
The three parameters are selected by one parameter to calculate the shelf life of liquid smoked tandipang fish which is considered to greatly affect the quality degradation during storage. The relationship line equation between $\ln \mathrm{k}$ and 1 / $\mathrm{T}$ is used to determine the value of activation energy (Ea) in the Arrhenius model (Figure. 5). Activation energy in liquid smoked tandipang fish uses a slope of the order 1 chart at $a_{w}$ values. Activation energy describes the magnitude of the effect of temperature on the reaction. The straight graph slope of the relationship between $\ln \mathrm{k}$ and $(1 / \mathrm{T})$ produces activation energy or it can be formulated by Ea = R x slope (Haryati et al., 2014). 
Parameters for determining shelf life use $\mathrm{a}_{\mathrm{w}}$ value. The peroxide and TPC numbers have $\mathrm{R}^{2}$ values below 0.5 so it cannot be continued to determine shelf life. Pulungan et al., (2019) stated Determination of shelf life based on the parameters that experienced the fastest decline indicated by the value of the highest correlation coefficient $\left(\mathrm{R}^{2}\right)$.

$$
10461=\frac{E a}{R}
$$

$\mathrm{Ea}=10461 \times 8.314=86972.75 \mathrm{~J} / \mathrm{mol} . \mathrm{K}$

Based on the calculation results, the $\mathrm{a}_{\mathrm{w}}$ activation energy value is $86972.75 \mathrm{~J} / \mathrm{mol} . \mathrm{K}$. If the liquid smoked fish is stored at room temperature, namely $27^{\circ} \mathrm{C}$ with a basic quality value of a sample (Q0) of 0.67 and a final quality limit (Qt) of 0.90 , then it can be assumed that the shelf life is as follows the line equation in Figure 1 which the best order 1 the $a_{w}$ parameter (Tabel. 4). If the temperature (T) is $27{ }^{\circ} \mathrm{C}$ or $300 \mathrm{~K}$, so In $\mathrm{k}$ is -4.614 , and $\mathrm{k}$ value is 0.00992 . Shelf life of liquid smoked fish stored at $27{ }^{\circ} \mathrm{C}$; according to equation $(2) \mathrm{t}=(\ln 0.9$-ln 0.67) /0.00992; obtained the value of $t=23.2$ (in units of weeks or 5.8 months of storage). In contrast to the results of research by Ismail et al., (2018) on the shelf life of roa fish. Determination of shelf life of roa fish refers to the lowest activation energy value, namely the water content of $-3417.91 \mathrm{cal} / \mathrm{mol}$. So that the shelf life of the roa fish is obtained, which is 7 months and 4 days.

The shelf life of a product varies depending on fish species (Nahid et al., 2017). the type of smoking direct/indirect combustion (Özpolat and Patir 2015), different salt concentration (Chatzikyriakidou and Katsanidisthe, 2012), duration of smoking, the level of concentration of liquid smoke added (Morey et al. 2012) and the drying process of the smoking fish method (Koral et al, 2010).

\section{Conclusion}

Based on the research results, it can be concluded that liquid smoke can extend shelf life. The parameters used in estimating the shelf life of liquid smoked tandipang fish are $a_{w}$, TPC, and peroxide number. The $a_{w}$ parameter is used to determine the shelf life because it has a high $\mathrm{R}^{2}$ value with an activation energy of $86972.75 \mathrm{~J} /$ mol.K. Estimation of shelf life of liquid smoked fish at room temperature using $\mathrm{a}_{\mathrm{w}}$ parameter is 23.2 weeks or 5.8 months.

\section{Acknowledgment}

We thank to The Marine and Fisheries Education Center (PUSDIK KP), Ministry of Marine Affairs and Fisheries Republic of Indonesia, that has provided research funding.

\section{Authors' Contributions}

Diyah Ayu Rakhmayeni do the research and write the article. Tatty Yuniarti was finished the manuscript and corresponded author also with Sukarno provide guidance and direction on article creation.

\section{Conflict of Interest}

The authors declare that they have no conflict of interests.

\section{Funding Information}

This research was supported by The Marine and Fisheries Education Center (PUSDIK KP), Ministry of Marine Affairs and Fisheries Republic of Indonesia.

\section{Refrences}

Abraha, B., Admassu, H., Mahmud, H, Tsighe, N., Shui, X.W., \& Fang Y. (2018). Effect of processing methods on nutritional and physico-chemical composition of fish: a review. MOJ Food Process Technol, 6(4):376-382.

Agustina, R., Hendri, S., \& Ridha, M., (2013). Kajian mutu ikan lele (Clarias Batrachus) asap kering. Jurnal Teknologi dan Industri Pertanian Indonesia, 5(3): 6-11.

Alcicek, Z. (2014). Effects of different liquid smoke flavor levels on the shelf life of venus clam (Chamelea Gallina, L 1758) Meat. Journal of Food Processing and Preservation. 38(3): 964-970.

Anihouvi, D. G. H., Kpoclou, Y. E., Massih, M. A., Afé, O. H. A. I., Assogba, M. F., Covo, M., Scippo, M. L., Hounhouigan, D. J., Anihouvi, V., \& Mahillon, J. (2019). Microbiological characteristics of smoked and smoked dried fish processed in Benin. Food Science and Nutrition, 7(5): 1821-1827.

Asriyana, Rahardjo, M. F., Kartamihardja, E. S., \& Lumban, B. F. (2010). Food habit of rainbow sardine, Dussumieria acuta Valenciennes, 1847 (Family: Clupeidae) in Kendari Bay. Jurnal Iktiologi Indonesia, 10(1): 93-99.

[AOCS] American Oil Chemists Society. (1998).Official methods and recommended practices of the American Oil Chemists'Society, 5th ed. AOCS Press, Champaign.

Belichovska, K., Belichovska. D., \& Pejkovski, Z. (2019). Smoke and smoked fish production, Scientific Journal Meat Technology, 60(1): 39-43.

Belitz, H. D., Grosch, W., \& Schieberle, P. (2009). Springer food chemistry 4th revised and extended edition. Annual Review. Biochemistry, 79:655681. 
Bhuyan, D., Das, A., Laskar, S. K., Bora, D. P, Tamuli S., \& Hazarika, M. (2018) Effect of different smoking methods on the quality of pork sausages, Veterinary World, 11(12): 1712-1719.

Bin, F., \& Labuza, T. P. (2013). Shelf life testing: Procedures and prediction methods for frozen foods.

Chatzikyriakidou, K., \& Katsanidis E. (2012). Effect of liquid smoke dipping and packaging method on the keeping quality of raw and cooked chub mackerel (Scomber japonicus) fillets. Journal of Aquatic Food Product Technology. 21(5): 445-454.

Danarsi, C. S, \& Noer, E.R., (2016). Pengaruh lama penyimpanan terhadap mutu mikrobiologi makanan pendamping air susu ibu (Mp-Asi) bubur instan dengan substitusi tepung ikan gabus dan tepung labu kuning. Thesis. Diponegoro University

Hadinito, S. (2016). Karakteristik mutu ikan cakalang (Katsuwonus pelamis) asap. E-Jurnal Balai Riset dan Standarisasi Industri Ambon, 12(1): 12-26.

Haryati, H., Estiasih, T., Sriherfyna, F. H., \& Ahmadi, K. (2014). Pendugaan umur simpan menggunakan metode Accelerated Shelf-Life Testing (ASLT) dengan pendekatan arrhenius pada produk tape ketan hitam khas mojokerto hasil sterilisasi. Jurnal Pangan dan Agroindustri, 3(1): 156-165.

Helmi, H., \& Fadli, M. (2014). Penentuan umur simpan (shelf life) pundang seluang (rasbora sp) yang dikemas menggunakan kemasan vakum dan tanpa vakum. Jurnal Saintek Perikanan, 9(2): 53-62.

Hasany, M. R., Afrianto, E., \& Pratama, R. I. (2017). Pendugaan umur simpan menggunakan metode Accelerated Shelf Life Test (ASLT) model arrhenius pada fruit nori. Jurnal Perikanan Kelautan, 8(1): 48-55.

Herawati, E.R.N., Nurhayati, R., Agwar, M., Wakhida, V., \& Katri, R.B. (2017). Pendugaan umur simpan keripik pisang salut cokelat "purbarasa" berdasarkan angka thio barbituric acid (TBA) dengan metode Accelerated Shelf-Life Testing (ASLT) model Arrhenius. Reaktor, 17(3): 118-125.

Herawati, H. (2008). Penentuan umur simpan pada produk pangan. Jurnal Litbang Pertanian, 27(4): 124130.

Hokkanen M., Luhtasela U., Kostamo P., Ritvanen T., Peltonen K, \& Jestoi M. (2018). Critical effects of smoking parameters on the levels of polycyclic aromatic hydrocarbons in traditionally Smoked fish and meat Products in Finland. Hindawi Journal of Chemistry, (2018): 1-14.

Ismail, H., Hamidin, R., \& Saleh, E.R.M. (2018). penentuan umur simpan ikan roa asap (ikan julung-julung asap) (Hemirhampus sp) menggunakan metode ASLT (Accelerated Shelf Life Testing) dengan pendekatan Arrhenius. Techno: Jurnal Penelitian, 7(1): 105-115.
Ijabadeniyi, O. A., \& Pillay, Y. (2017). Microbial safety of low water activity foods: study of simulated and durban household samples. Hindawi: Journal of Food Quality. 2017: 1-7

Kailaku, S. I., Syakir, M., Mulyawanti, I., \& Syah, A. N. A. (2017). Antimicrobial activity of coconut shell liquid smoke. 29th Symposium of Malaysian Chemical Engineers (SOMChE) 2016. IOP Conference Series: Materials Science and Engineering, 206(2017):1-6.

Ketaren, S. (2012). Minyak dan lemak pangan. Universitas Indonesia. Jakarta.

Karapang, R., Harikedua, S. D., Suwetja, I. K. (2013). Penentuan mutu ikan tandipang (Dussumeiria acuta $\mathrm{CV}$ ) asap kering selama penyimpanan suhu kamar. Jurnal Media Teknologi Hasil Perikanan. 1(1): 1-6.

Koral, S., Köse, S., \& Tufan, B. (2010). The effect of storage temperature on the chemical and sensorial quality of hot smoked atlantic bonito (Sarda sarda, Bloch, 1838) packed in aluminium foil. Turkish Journal of Fisheries and Aquatic Sciences. 10(4): 439-443.

Lingbeck, J. M., Cordero, P., O’Bryan, C. A., \& Johnson, M. G. (2014). Functionality of liquid smoke as an all-natural antimicrobial in food preservation. Meat Science, 97(2):197-206.

Lokollo, E., Apituley, D. A. N., \& Nendissa, D.M. (2012). Pengolahan ikan cakalang (katsuwonus pelamis) asap dengan menggunakan teknologi asap cair. Jurnal of Community Service 1(2): 165-169.

Lombok, J.Z., Setiaji, B., Trisunaryanti, W., \& Wijaya, K. (2014). Effect of pyrolisis temperature and distillation on character of coconut shell liquid smoke. Proceeding of International Conference On Research, Implementation and Education of Mathematics And Sciences 2014, Yogyakarta State University, 18-20 May 2014. ISBN. 978979-99314-8-1. C87-C96

Maharani, D. M., Bintoro, N., \& Rahardjo, B. (2012). Kinetika perubahan ketengikan (rancidity) kacang goreng selama proses penyimpanan. Agritech, 32(1): 15-22.

Morey, A., Bratcher, C. L., Singh, M., \& McKee, S. R. (2012). Effect of liquid smoke as an ingredient in frankfurters on Listeria monocytogenes and quality attributes. Poultry science, 91(9): 23412350.

Mulyawanti, I., Kailaku, S. I, Syah, A. N. A., \& Risfaheri. (2019). Chemical Identification of Coconut Shell Liquid Smoke. 2nd International Conference on Agriculture Postharvest Handling and Processing. IOP Conf. Series: Earth and Environmental Science 309 (2019) 012020. 
Nahid, N. M., Latifa, G. A., Chakraborty, S. C., Farid, F. B., \& Begum, M. (2017), The determination of shelf life quality of three smoke-dried freshwater fishes in refrigeration storage. International Journal of Advanced Scientific Research. 2(1): $17-24$.

Najih, M. A., Swastawati, F., \& Agustini, T.W. (2014). Pengaruh perbedaan jenis dan lama perendaman asap cair terhadap karakteristik arabushi ikan tongkol (Euthynnus affinis). Jurnal Pengolahan dan Bioteknologi Hasil Perikanan, 3(4): 25-30.

Nanlohy, E. E. (2014). Analisa total bakteri pada ikan tuna asap yang direndam dengan asap cair "waa sagu" selama penyimpanan pada suhu kamar. Majalah Biam, 10(2):90-95.

Özpolat, E., \& Patir, B. (2015). Determination of Shelf Life for Sausages Produced From Some Freshwater Fish Using Two Different Smoking Methods. Journal of Food Safety. 36(1): 69-76.

Peraturan Pemerintah Republik Indonesia. Nomor 69 Tahun 1999 Tentang Label dan Iklan Pangan.

Phimolsiripol, Y., Siripatrawan, U., \& Cleland, D.J. (2011). Weight loss of frozen bread dough under isothermal and fluctuating temperature storage conditions. Journal of Food Engineering. 106(2): 134-143.

Phimolsiripol, Y., \& Suppakul, P. (2016). Techniques in shelf life evaluation of food products. reference module in food sciences. Elsevier: 1-8.

Pulungan, M. H., Sukmana, A. D., \& Dewi, I. A. (2019). Shelf life prediction of apple brownies using accelerated method. International Conference on Green Agro-industry and Bioeconomy: IOP Conf. Series: Earth and Environmental Science 131 (2018) 012019. IOP Publishing.

Putri, A. M., \& Kurnia, P. (2018). Identifikasi keberadaan bakteri coliform dan total mikroba dalam es dungdung di sekitar kampus Universitas Muhammadiyah Surakarta. Media Gizi Indonesia 13(1): 41-48.
Sanger, G. (2010). Oksidasi lemak ikan tongkol (Auxis thazard) asap yang direndam dalam larutan ekstrak daun sirih. Pasific Journal, 2(5): 870-873.

Salokoa, S., Dramadji, P., Setiaji, B., \& Pranoto, Y., (2014). Antioxidative and antimicrobial activities of liquid smoke nanocapsules using chitosan and maltodextrin and its application on tuna fish preservation. Food Bioscience, 7 (2014): 71-79.

Schlossman, N., Johnson. Q., Wood. L., Coglianese. N., Santoso. V., \& Koeppel. L. (2015). Accelerated shelf life studies: methods and results relating to new and upgraded food aid products. USAID Food Aid Quality Review Phase.

SNI. (2013). Ikan asap dengan pengasapan panas. SNI No. 2725:2013. Badan Standarisasi Nasional.

Sutanaya, N. T. A., Kencana, P. K. D., Arda, G. (2018). Application of coconut shell liquid smoke is able to prolong tuna fish fillet shelf life. Jurnal Beta (Biosistem Dan Teknik Pertanian). 6(2): 82-89.

Swadana, A.W., \& Sudarminto, S. Y. (2014). Pendugaan umur simpan minuman berperisa apel menggunakan metode Accelerated Shelf-Life Testing (ASLT) dengan pendekatan Arrhenius. Jurnal Pangan dan Agroindustri, 2(3):203-213.

Swastawati, F., Surti, T., Agustini, T. W., Riyadi, P. H. (2015). Benzo $(\alpha)$ pyrene potential analysis on smoked fish (case study: traditional method and smoking kiln). The 1st International Symposium on Aquatic Product Processing 2013. Published by Knowledge Publishing Services.

Utomo, B. S. B., Wibowo, S., \& Widianto, T. N. (2012). Asap cair. Penebar Swadaya. Jakarta.

Wiguna, D. (2011). Pengaruh suhu dan transparansi kemasan terhadap stabilitas kapasitas antioksidan sebagai parameter umur simpan bir pletok. Skripsi. Bogor. Institute Pertanian Bogor.

Winarno, F. G. (2007). Teknobiologi Pangan. Mbrio Press. Bogor. 